П.Н. Чирвинского: сборник научных статей. ПГНИУ. Пермь, 2021. Вып. 24

УДК 552.5

\author{
ГЕОЛОГИЯ УГЛЕРОДИСТЫХ ОТЛОЖЕНИЙ \\ БИРГИЛЬДИНСКОЙ ТОЛЩИ \\ (ВОСТОЧНО-УРАЛЬСКИЙ ПРОГИБ)
}

А.В. Сначёв ${ }^{1}$, К.Р. Нуриева ${ }^{1,2}$, Р.Р. Исламов ${ }^{1,2}$

${ }^{1}$ Институт геологии УФИЦ РАН, г. Уфа

2 Башкирский Государственный Университет, г. Уфа

В статье приводится описание геологического строения биргильдинской толщи широко развитой в Восточно-Уральском прогибе. Показано, что биргильдинские черные сланцы, имеющие в своем составе $\mathrm{C}_{\text {орг }}$ в пределах $0,5-2,7 \%$ (среднее $1,3 \%$ ), относятся к низкоуглеродистому типу. Экзотермический эффект в них происходил в основном в интервале температур $570-660^{\circ} \mathrm{C}$, что соответствует зеленосланцевой фации регионального метаморфизма. На диаграмме A-S-C породы биргильдинской толщи приблизительно поровну разбросаны по карбонатно-углеродистому и кремнисто-углеродистому полям и заметно меньше - терригенно-углеродистому. Для биргильдинской толщи характерны коллизионная обстановка накопления и продукты разрушения главным образом основных магматических пород.

Ключевые слова: Биргильдинская толща, углеродистые отложения, черные сланцы, метаморфизм, палеогеография.

\title{
DOI: 10.17072/chirvinsky.2021.223
}

Статья написана на основе материала, полученного в процессе проведения совместно с сотрудниками ОАО «Челябинскгеосъемка» геолого-съемочных и научно-исследовательских работ М 1:200 000 в пределах листов N-41-XIII (Пласт) [4] и N-41-XIV (Троицк) [5]. Приграбенный блок расположен в крайней восточной части Восточно-Уральского прогиба на границе с Челябинским грабеном (широта города Троицк). Геологическое строение рассматриваемого участка довольно сложное, что связано с присутствием здесь тектонических разломов, которые привели к образованию серий субмеридиональных клавишных структур, выполненных преимущественно нижнекаменноугольными осадочными отложениями. C запада Приграбенный блок граничит с вулканогенными породами кособродской толщи ( $\left.\mathrm{D}_{2} \mathrm{ks}\right)$, а с востока - с метаморфитами городищенской свиты $\left(\mathrm{RF}_{3}-\mathrm{V}_{1} \mathrm{gr}\right)$ (рис. 1). В стратиграфическом разрезе снизу вверх выделяются четыре толщи: тугундинская $\left(\mathrm{C}_{1} \mathrm{tg}\right)$, биргильдинская $\left(\mathrm{C}_{1} \mathrm{bg}\right)$, еткульская $\left(\mathrm{C}_{1}\right.$ et) и ухановская $\left(\mathrm{C}_{2} \mathrm{uh}\right)$, из которых только в биргильдинской широко развиты углеродистые сланцы.

(C) А.В. Сначёв, К.Р. Нуриева, Р.Р. Исламов, 2021 


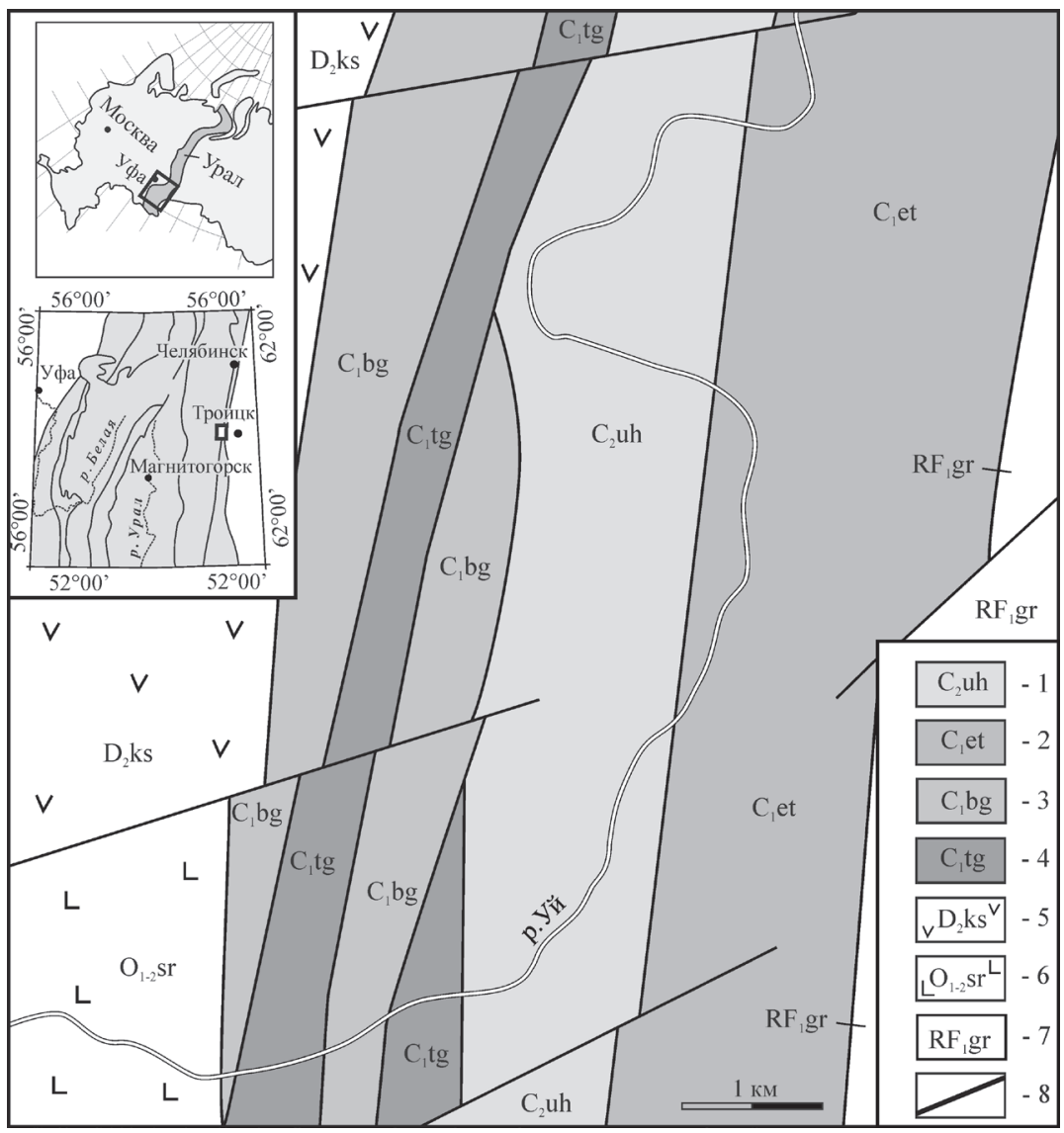

Рис. 1. Геологическая карта Приграбенного блока (составлена с использованием материалов Б.А. Пужакова и др. $[4,5])$ :

1 - ухановская толща (полимиктовые песчаники, конгломераты, гравелиты), 2 - еткульская толща (известняки с прослоями песчаников, алевролитов), 3 - биргильдинская толща (песчаники, гравелиты, углеродисто-глинистые сланцы, известняки), 4 - тугундинская толща (известняки, песчаники, алевролиты, часто углеродистые), 5 - кособродская толща (андезиты, андезито-базальты, их туфы), 6 - саргазинская толща (базальты), 7 - городищенская свита (зеленые сланцы, метабазальты, филлиты), 8 - разрывные нарушения.

По данным Б.А. Пужакова и др. [4, 5] на западном фланге рассматриваемой территории она сложена аркозовыми и полимиктовыми песчаниками, гравелитами и конгломератами, алевролитами и аргиллитами, которые вверх по разрезам с переслаиванием сменяются светлосерыми, 
темносерыми глинистыми и углеродистыми известняками, а на восточном - основу разреза составляют карбонатные породы, представленные известняками мраморизованными белыми и серыми органогенными, мраморами, кальцифирами; прослоями углеродисто-глинистых, известково-глинистых сланцев, алевролитов, песчаников. Толща согласно залегает на тугундинских образованиях. Взаимоотношения с вышележащими ухановскими отложениями несогласные. Мощность её до 500м. Породы толщи являются благоприятной средой для локализации свинцово-цинкового, бериллиевого, золото-сульфидного и уранового оруденения. Биргильдинская толща является рудовмещающей для золоторудных объектов $[6,9]$. Визе-серпуховской её возраст определен по многочисленным находкам фауны фораминифер и брахиопод [4].

Обратимся к рассмотрению условий образования и метаморфизма черных сланцев. Вначале следует остановиться на классификации пород по содержанию в них $\mathrm{C}_{\text {орг }}$ Согласно Я.Э. Юдовичу и М.П. Кетрис [7], пограничное его значение между углеродистыми и неуглеродистыми отложениями составляет 1\%, низкоуглеродистые имеют в своем составе 1-3\% $\mathrm{C}_{\text {орг }}$, углеродистые - 3-10\%, высокоуглеродистые - >10\%. Нами был проведен термогравиметрический анализ 6 проб (табл. 1, рис. 2).

Таблица 1

Температуры экзотермического эффекта и содержания органического углерода в углеродсодержащих отложениях биргильдинской толщи

\begin{tabular}{|c|c|c|c|c|}
\hline № п/п & № пробы & $\mathrm{C}_{\text {орг }} \%$ & Начало эффекта, ${ }^{\circ} \mathrm{C}$ & Температура макс., ${ }^{\circ} \mathrm{C}$ \\
\hline 1 & А-06 & 1,2 & 570 & 660 \\
\hline 2 & А-07 & 2,7 & 540 & 700 \\
\hline 3 & А-17 & 0,5 & 510 & 570,600 \\
\hline 4 & А-29 & 0,9 & 590 & 630 \\
\hline 5 & А-33 & 1,2 & 570 & 630 \\
\hline 6 & А-36 & 1,4 & 570 & 630 \\
\hline
\end{tabular}

Примечание - Термогравиметрический анализ проводился на дериватографе Q-1500 (Венгрия) (аналитик Т.И. Черникова, ИГ УФИЦ РАН). Нагрев осуществлялся на воздухе от 20 до $1000{ }^{\circ} \mathrm{C}$ со скоростью $10{ }^{\circ} \mathrm{C} /$ мин.

Согласно табл. 1 биргильдинские черные сланцы, имеющие в своем составе $\mathrm{C}_{\text {орг }}$ в пределах 0,5-2,7\% (среднее 1,3\%), относятся к низкоуглеродистому типу. Экзотермический эффект в них происходил в основном в интервале температур $570-660^{\circ} \mathrm{C}$, что по данным В.П. Ивановой и др. [2] соответствует фации зеленых сланцев (пик с четко выраженным двойным максимумом в образце А-17 свидетельствует о его двухстадийном метаморфизме). Лишь одна проба (А-07) укладывается в интервал 
$660-700^{\circ} \mathrm{C}$ и относится к эпидотамфиболитовой фации регионального метаморфизма. В образце A-29 отмечается пик $850^{\circ} \mathrm{C}$, соответствующий температуре разложения карбонатов (до 16 мас.\%).

Известно, что углеродистые отложения представляют собой весьма информативные породы для реконструкции палеогеографических условий их накопления и выяснения источников сноса терригенного материала [1]. С этой целью в Институте геологии УФИЦ РАН (г. Уфа, аналитик С.А. Ягудина) был изучен химический состав 40 проб черных сланцев биргильдинской толщи. Результаты анализа вынесены на ряд следующих характеристических диаграмм: A-S-C [1], F1-F2 [8], DF1-DF2 [3, 10]. Фигуративные точки на диаграмме A-S-C образуют непрерывный ряд по осям: А - от (+130) до (-260) ед., S - от 200 до 1550 ед., С - от 0 до 21 ед. Образования биргильдинской толщи приблизительно поровну разбросаны по карбонатно-углеродистому и кремнисто-углеродистому полям и заметно меньше - терригенно-углеродистому. Учитывая обратнопропорциональную зависимость параметра $\mathrm{S}$ и доли терригенной примеси в осадках, которая в свою очередь служит основным индикатором удаленности участка седиментации от береговой линии водного бассейна, можно предположить, что в поздневизейское время (терригенные породы нижней части разреза биргильдинской толщи) глубина водного бассейна несколько увеличилась, а в серпуховское (карбонатные породы верхней части разреза биргильдинской толщи) - вновь происходит постепенная регрессия и обмеление бассейна, которое продолжалось вплоть до московского времени.

C помощью диаграмм F1-F2 и DF1-DF2 можно с большой долей вероятности восстановить источники терригенного материала в углеродистых сланцах и геодинамические условия их образования. Согласно данным диаграммам для отложений биргильдинской толщи характерна коллизионная обстановка накопления и продукты разрушения основных 
и переходных к кислым магматических пород.

Таким образом, изучение углеродистых отложений ВосточноУральского прогиба позволило сделать ряд следующих выводов:

1. Терригенные и карбонатные породы биргильдинской толщи относится к низкоуглеродистому типу и испытал региональный метаморфизм в условиях зеленосланцевой фации.

2. Осадки отлагались сначала в относительно глубоководных условиях, но позднее происходит постепенная регрессия и обмеление бассейна.

3. Для отложений биргильдинской толщи характерны коллизионная обстановка накопления и продукты разрушения главным образом основных магматических пород.

Работа выполнена в рамках Государственного заказа по теме № 0246-2019-0078

Библиографический список

1. Горбачёв O.В., Созинов Н.A. Некоторые петрохимические и геохимические аспекты типизации углеродистых отложений докембрия // Проблемы осадочной геологии докембрия. М.: Наука. 1985. С. 46-57.

2. Иванова В.П., Касатов Б.К., Красавина Т.Н., Розинова Е.Л. Термический анализ минералов и горных пород. Л.: Недра, 1974. 399 с.

3. Маслов А.В., Подковыров В.Н., Гареев Э.З., Котова Л.Н. Валовый химический состав песчаников и палеогеодинамические реконструкции // Литосфера. 2016. № 6. С. 33-55.

4. Пужаков Б.А., Шох В.Д., Щулькина Н.Е., Щулькин Е.П., Долгова О.Я., Орлов М.В., Попова Т.А., Тарелкина Е.А., Иванов А.В. Государственная геологическая карта Российской Федерации. Масштаб 1:200 000. Издание второе. Серия Южно-Уральская. Лист N-41-XIII (Пласт). Объяснительная записка. М.: «ВСЕГЕИ», 2018. $205 \mathrm{c}$.

5. Пужаков Б.А., Шох В.Д., Щулькина Н.Е., Щулькин Е.П., Тарелкина Е.А., Долгова О.Я., Орлов М.В., Попова Т.А., Тарелкина Е.А. Государственная геологическая карта Российской Федерации. Масштаб 1:200 000. Издание второе. Серия Южно-Уральская. Лист N-41-XIV (Троицк). Объяснительная записка. М.: «ВСЕГЕИ», 2018. $238 \mathrm{c}$.

6. Сначёв А.В., Сначёв В.И., Рассомахин М.А., Коломоеи А.В. Углеродистые сланцы Каменского участка: геология и рудоносность (Южный Урал) // Горный журнал. 2020. № 2. С. 34-38.

7. Юдович Я.Э., Кетрис М.П. Геохимия черных сланцев. Л.: Наука, 1988. 271 с. 8. Roser. B.P., Korsch. R.J. Provenance signatures of sandstone-mudstone suites determined using discriminant function analysis of major-element data // Chemical Geology. 1988. V. 67. P. 119-139.

9. Snachev A.V., Snachev V.I. Gold bearing black shales of the Kamensk structure (Chelyabinsk graben. South Urals) / Kazan Golovkinsky Stratigraphic Meeting. 2019 Sedimentary Earth Systems: Stratigraphy. Geochronology. Petroleum Resources. Proceedings. 2019. C. 229-234.

10. Verma S.P., Armstrong-Altrin J.S. New multi-dimensional diagrams for tectonic discrimination of siliciclastic sediments and their application to Precambrian basins // Chemical Geology. 2013. V. 355. P. 117-133. 


\section{GEOLOGY OF CARBONACEOUS DEPOSITS OF THE BIRGILDA STRATA (EAST URAL TROUGH) \\ A.V. Snachev, K.R. Nurieva, R.R. Islamov \\ SAVant@rambler.ru}

The article describes the geological structure of the Birgilda strata, which is widely developed in the East Ural trough. It is shown that the Birgilda black shales, which contain Corg in the range of $0.5-2.7 \%$ (average $1.3 \%$ ), are of the low-carbon type. The exothermic effect in them occurred mainly in the temperature range $570-660{ }^{\circ} \mathrm{C}$, which corresponds to the greenschist facies of regional metamorphism. On the A-S-C diagram, the rocks of the Birgilda strata are approximately equally scattered over the carbonate-carbonaceous and siliceous-carbonaceous fields and noticeably less in the terrigenous-carbonaceous fields. The Birgilda sequence is characterized by a collisional environment of accumulation and products of destruction of mainly basic igneous rocks.

Keywords: Birgilda strata, carbonaceous deposits, black shales, metamorphism, paleogeography 